\title{
Alkaline Pre-Treatment and Enzymatic Hydrolysis of Waste Papers to Fermentable Sugar
}

\section{Modupe Elizabeth Ojewumi ${ }^{1 *}$, Barbra ljeoma Obielue ${ }^{1}$, Moses Eterigho Emetere ${ }^{2}$, Olugbenga Olufemi Awolu³, Emmanuel Omotayo Ojewumi}

\author{
1 Chemical Engineering Department, Covenant University, P.M.B 1023, Canaan Land, Ota, Ogun State, Nigeria \\ 2 Department of Physics, Covenant University, P.M.B 1023, Canaan Land, Ota, Ogun State, Nigeria \\ 3 Department of Food Science and Technology, Federal University of Technology, Akure, Ondo-State, Nigeria \\ * Corresponding author e-mail: modupe.ojewumi@covenantuniversity.edu.ng
}

\begin{abstract}
Waste paper is known to be the major component of organic solid waste. In this research, waste paper was used as a feedstock for the production of fermentable sugar with the aid of two (2) microorganisms. The waste papers used included newspaper, office paper and foolscap paper. Enzymatic hydrolysis was carried out on the waste papers after the alkaline treatment using Aspergillus niger and Pseudomonas aeruginosa at different temperatures of $25^{\circ} \mathrm{C}, 37^{\circ} \mathrm{C}$ and $42^{\circ} \mathrm{C}$. The highest yield was obtained from the foolscap paper, which produced reducing sugar at a maximum concentration of $486.66 \mathrm{mg} / \mathrm{L}$ after two weeks using Pseudomonas aeruginosa at $37^{\circ} \mathrm{C}$. On the other hand, hydrolysing using Aspergillus niger, produced reducing sugar at a maximum concentration of $365 \mathrm{mg} / \mathrm{L}$ at an optimum temperature of $25^{\circ} \mathrm{C}$ with office paper.
\end{abstract}

Keywords: enzymatic hydrolysis, fermentable sugars (glucose), microorganisms, waste papers.

\section{INTRODUCTION}

Papers are usually discarded indiscriminately leading to environmental pollution by littering and burning. The accumulation of excess volumes of solid waste such as the waste paper and the search for clean energy are topical global issues [14]. Its recent discovery in industries has helped to curb the environmental pollution, as these papers can be recycled so that they can be re-used instead of being wasted [10]. The environmental pollution may not have a direct effect on the economy, but it has adverse effects on the human population, especially on the health sector. Moreover, instead of wasting away these papers, they can be utilised for the production of fermentable sugars as they constitute lignocellulosic materials which contain cellulose, a major component for sugar production. The conversion of lignocellulosic material to fermentable sugar is an important step in the production of bioethanol [16].
Environmental conservation and limiting the production waste materials by recycling it to useful products can never be over-emphasized [19]. Solid waste does not only occupy valuable land but also contributes largely towards environmental pollution [12].

An analysis of the amount of solid waste produced annually revealed that the waste paper is a major component of solid waste materials [9]. A substantial amount of waste paper is being generated daily within the University premises. This has been a major concern to the institution, because these waste papers are been disposed by incineration which has a negative health implication on human beings. Other organic waste materials such as garden waste, kitchen waste and agricultural waste also contribute to solid waste generation [17].

Lignocellulosic biomass such as paper materials are the leafy or woody part of plants principally composed of the compounds cellu- 
lose, hemicellulose, and lignin. Cellulose [1], a primary component of plant cell walls, is made up of long chains of glucose linked by (b-1,4)glucosidic bonds. Newspaper contains almost $61 \%$ cellulose and $16 \%$ hemicellulose making these materials good sources of sugars [3].

Fermentable sugars are sugars that can be broken down by yeast to produce bio-ethanol, which is an alternative to the use of fossil fuels, and is more environmentally friendly, as combustion of fossil fuels leads to the emission of greenhouse gases which causes the global warming [10].

Guerfali et al. [4] reported that the enzymatic hydrolysis was carried out on two different types of waste paper, namely newspaper and office paper. The papers were hydrolysed using Trichorderma ressei and Aspergillus niger cultures. Under optimal conditions, it was found that the maximum yields of reducing sugar produced from the newspaper and office paper were $67 \%$ and $92 \%$.

The current work describes the conversion of waste papers into fermentable (reducing) sugar using the cellulose of both Aspergillus niger and Pseudomonas aeruginosa at different temperatures. It also aims at determining the type of waste paper that will produce the highest yield of fermentable sugar.

\section{MATERIALS AND METHODS}

The biomass (waste paper) used were obtained from different areas in Covenant University, Ota in Nigeria, such as the library, offices and the photocopying shops.

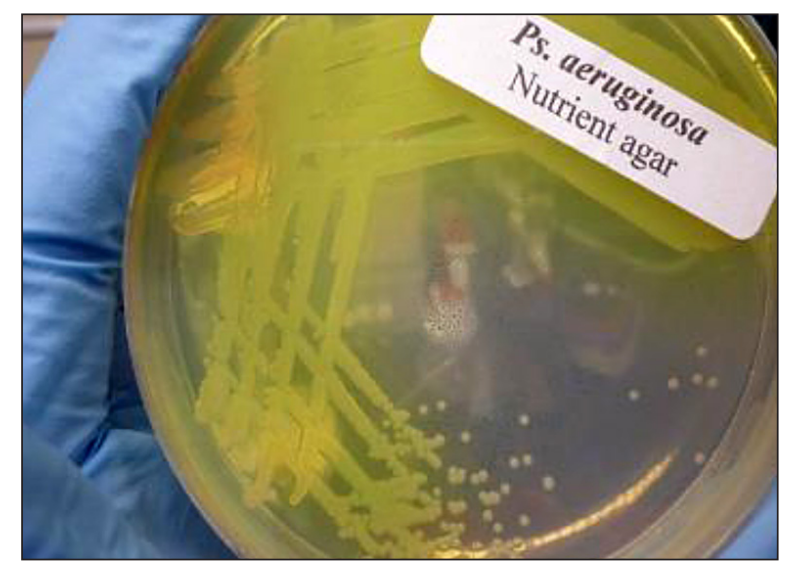

Figure 1. Pseudomonas aeruginosa plate

\section{Preparation of cellulase}

Aspergillus niger and Pseudomonas aeruginosa (environmental isolates), were sourced from the Applied Biology and Biotechnology Unit of the Biological Sciences, Covenant University, Ota, Ogun State, Nigeria. Both isolates were stored on Sabourad Dextrose Agar (SDA) slant. The isolates were sub-cultured on SDA sterile plate and incubated at $27^{\circ} \mathrm{C}$ for 3 to 5 days. Each isolate was adjusted to $0.5 \mathrm{McF}$ arland and used for the remediation. Figures 1 and 2 shows the plates of both Pseudomonas aeruginosa and Aspergillus niger respectively.

\section{De-inking and alkaline pre-treatment}

The waste papers were sorted to remove impurities such as pins and dirt. The papers were cut into smaller sizes of $1 \mathrm{~cm}$ by $1 \mathrm{~cm}$. The substrates were soaked in $4 \%$ sodium hypochlorite for 24 hours. It was then washed with water until neutralized ( $\mathrm{pH}$ of 7). The sample was left to dry overnight at $105^{\circ} \mathrm{C}$.

$5 \mathrm{~g}$ of each paper substrate was soaked in $60 \mathrm{ml}$ of $\mathrm{NaOH}(1 \%)$ solution in a flask and kept of $24 \mathrm{hrs}$. The alkali treated substrates were filtered through a muslin cloth, and washed in running tap water until neutralized. The excess water was removed by squeezing the substrate in a muslin cloth. De-inking was carried out in order to remove the ink particles present in the papers. This is because the ink particles hinder the effective hydrolysis, since it contains high ash content with inorganic fillers such as calcium carbonate and clay which is been added to improve the printing properties $[2,8]$.

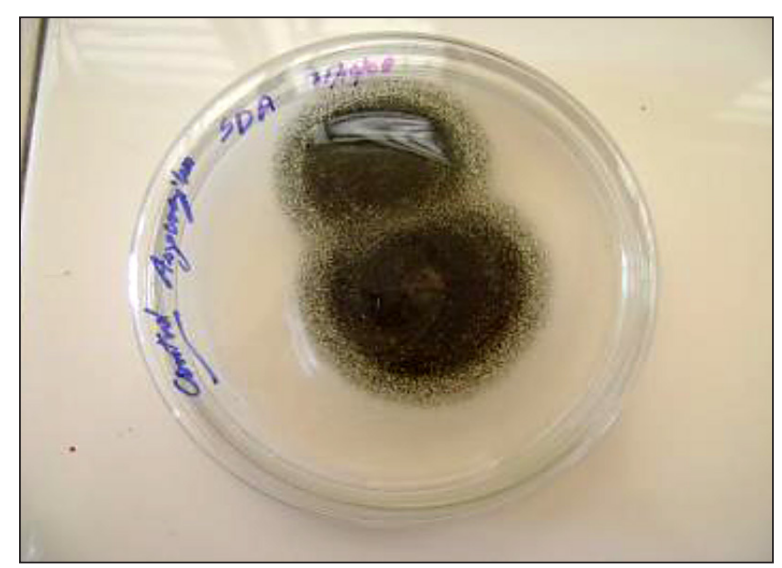

Figure 2. Aspergillus niger plate 


\section{Enzymatic hydrolysis}

The inoculi (Aspergillus niger and Pseudomonas aeruginosa) were introduced into the culture medium with a metal wire or loop which was rapidly sterilized before each use by heating it in a flame. The pre-treated papers (newspaper, office paper and foolscap paper) substrate were mixed with the enzyme solution $(100 \mathrm{ml})$ and incubated for three (3) weeks at $25^{\circ} \mathrm{C}$ and $37^{\circ} \mathrm{C}$ for the substrates with Aspergillus niger enzyme solution and $37^{\circ} \mathrm{C}$ and $42^{\circ} \mathrm{C}$ for the substrates with Pseudomonas aeruginosa enzyme solution. The samples were withdrawn weekly and analysed using the dinitrosalicyclic acid method for testing of reducing sugars.

Nutrient broth was added to the samples after every five days to keep the microorganisms alive. Figure 3 shows the diagram for the conversation of waste paper to fermentable sugar.

\section{Test for reducing sugar}

The test for reducing sugar was carried out using the dinitrosalicyclic acid test. The absorbance was recorded for each sample that was collected. The concentration of reducing sugar produced was calculated from their absorbance using the equation below from beer-lambert's law by plotting a standard calibration curve.

$$
A=e \cdot b \cdot C
$$

where: $A=$ absorbance

$$
\begin{aligned}
& e=\text { molar absorptivity }\left(\mathrm{m}^{2} / \mathrm{mol}\right) \\
& b=\text { path length }(\mathrm{m}) \\
& C=\text { concentration }\left(\mathrm{mol} / \mathrm{m}^{3}\right) .
\end{aligned}
$$

From the standard calibration curve, the slope was obtained to be 0.0006 , which is equal to the multiplication of the molar absorptivity and path length. Therefore,

$$
e \cdot b=0.0006 \mathrm{~L} / \mathrm{mg} \text {. }
$$

The absorbance of the samples was converted to concentrations using the standard calibration curve as shown in Figure 4, where:

$$
C=\frac{A}{0.0006}
$$

\section{RESULTS AND DISCUSSION}

Figure 5 shows the plot of concentration against time at $37^{\circ} \mathrm{C}$ using Aspergillus niger on the three (3) biomasses used with an increasing trend of sugar formation. Both foolscap and office paper yielded a high concentration of fermentable sugar with foolscap yielding about $288.33 \mathrm{mg} / \mathrm{L}$ while newspaper (NA) yielded the lowest concentration of reducing sugar during the hydrolysis period of three weeks, which corresponded with the findings of $[6,8]$.

Figure 6 shows the plot of concentration against time at $25^{\circ} \mathrm{C}$ using Aspergillus niger. Aspergillus niger that proved the office paper to be the most susceptible towards this enzyme-catalysed saccharification at $25^{\circ} \mathrm{C}$ with an increasing trend in sugar formation followed by foolscap paper and newspaper $[18,6]$.

Figure 7 shows the plot of concentration against time at $37^{\circ} \mathrm{C}$ using Pseudomonas aeruginosa. It showed that office paper had a maximum bioconversion towards the enzyme-catalysed saccharification at $37^{\circ} \mathrm{C}$, followed by the foolscap paper and newspaper.

Figure 8 shows the plot of concentration against time at $42^{\circ} \mathrm{C}$ where Pseudomonas aeruginosa indicated the office paper to be the most susceptible towards this enzyme-catalysed saccharification at $42^{\circ} \mathrm{C}$, followed by the newspaper and foolscap paper. An increasing trend in the production of sugar was also observed with a decreased time.

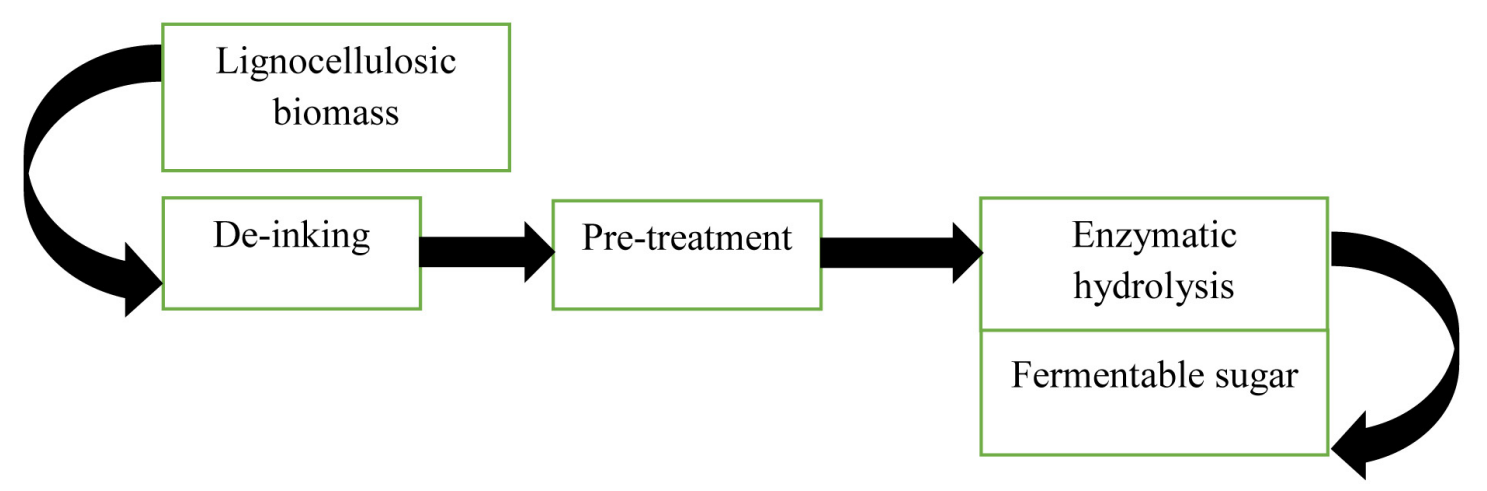

Figure 3. Block diagram for the production of fermentable sugar 


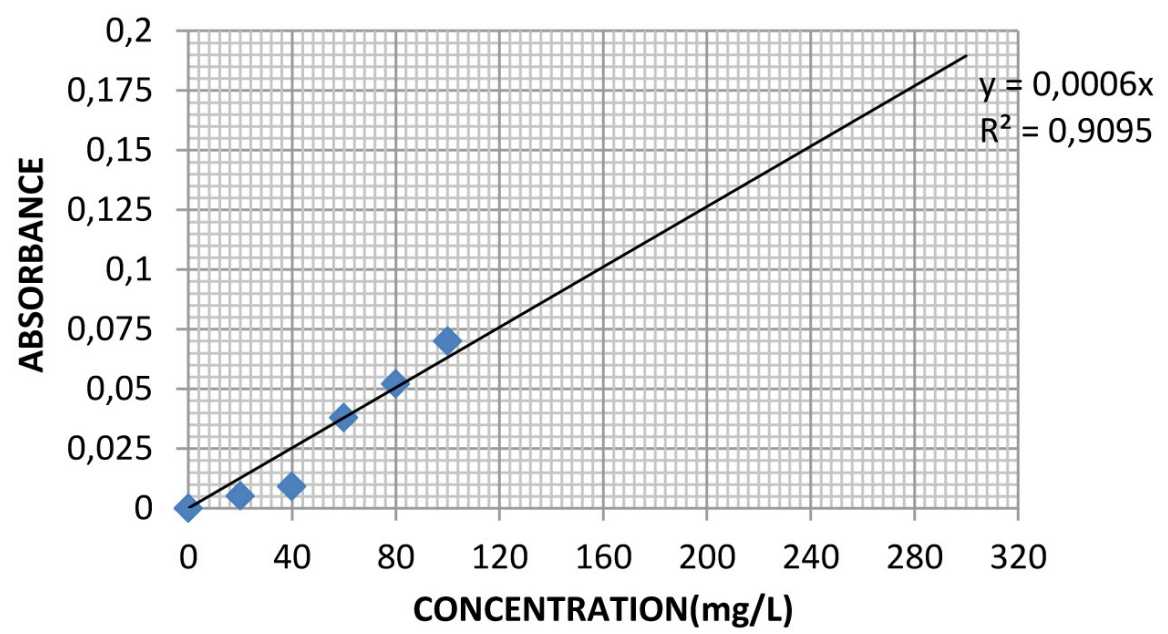

Figure 4. Standard calibration curve

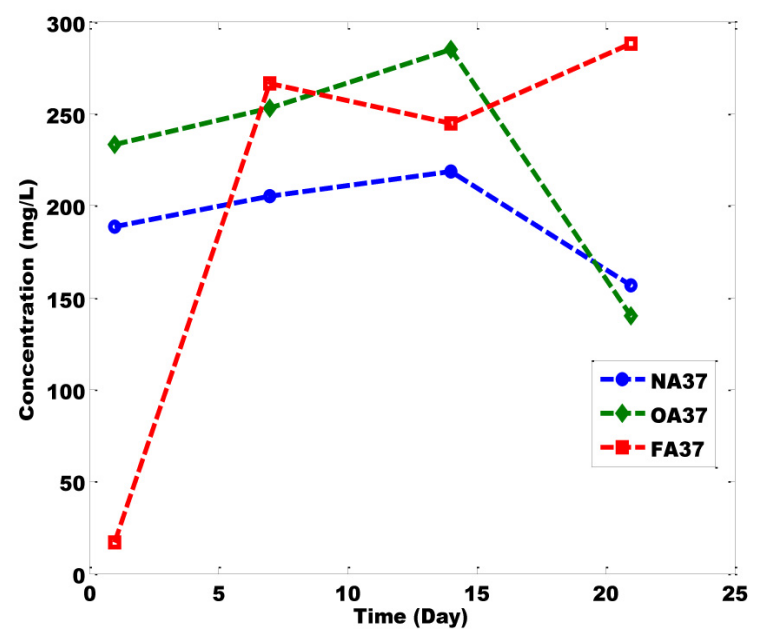

Figure 5. Plot of concentration against time at $37^{\circ} \mathrm{C}$ using Aspergillus niger

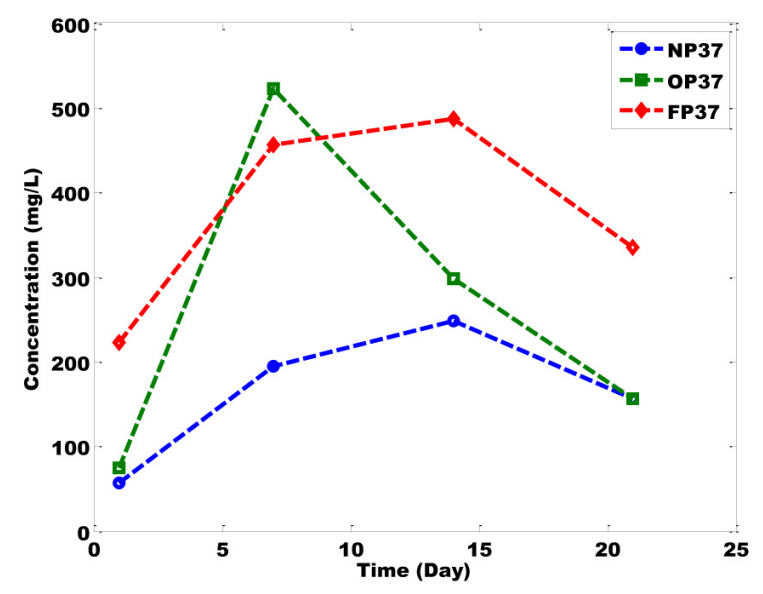

Figure 7. Plot of concentration against time at $37^{\circ} \mathrm{C}$ using Pseudomonas aeruginosa

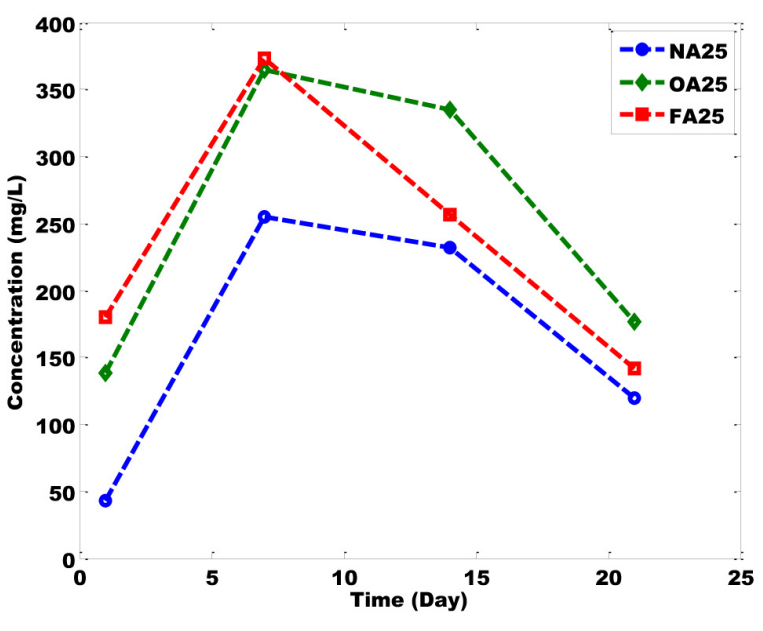

Figure 6. Plot of concentration against time at $25^{\circ} \mathrm{C}$ using Aspergillus niger

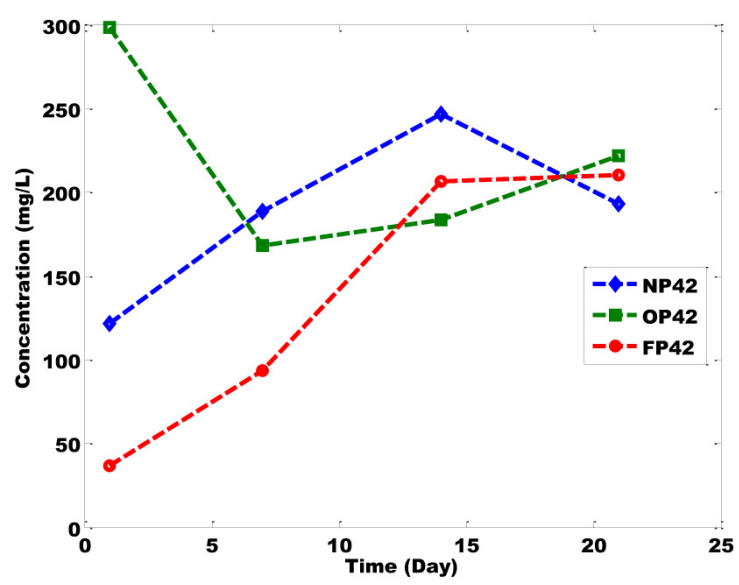

Figure 8. Plot of concentration against time at $42^{\circ} \mathrm{C}$ using Pseudomonas aeruginosa

Key: NA: Newspaper using Aspergillus niger at $25^{\circ} \mathrm{C}$, OA: Office paper using Aspergillus niger at $25^{\circ} \mathrm{C}$, FA: Foolscap paper using Aspergillus niger at $25^{\circ} \mathrm{C}$, NA: Newspaper using Aspergillus niger at $37^{\circ} \mathrm{C}$, OA: Office paper using Aspergillus niger at $37^{\circ} \mathrm{C}$, FA: Foolscap paper using Aspergillus niger at $37^{\circ} \mathrm{C}$, NP: Newspaper using Pseudomonas aeruginosa at $42^{\circ} \mathrm{C}$, OP: Office paper using Pseudomonas aeruginosa at $42^{\circ} \mathrm{C}$, FP: Foolscap using Pseudomonas aeruginosa at $42^{\circ} \mathrm{C}$ 
Comparing figures 5-8, it was observed from the plots that in order to achieve high yield of reducing sugar from newspaper, it should be hydrolysed using Pseudomonas aeruginosa at $37^{\circ} \mathrm{C}$ for two weeks or Aspergillus niger at $25^{\circ} \mathrm{C}$ for one week and to achieve high yield of reducing sugar from the office paper, it should be hydrolysed using Pseudomonas aeruginosa at $37^{\circ} \mathrm{C}$ for one week. In order to achieve high yield of reducing sugar from foolscap, it should be hydrolysed using Pseudomonas aeruginosa at $37^{\circ} \mathrm{C}$ for two weeks [5, 11].

Pseudomonas aeruginosa works more efficiently at a temperature of $37^{\circ} \mathrm{C}$ than at a temperature of $42^{\circ} \mathrm{C}$. Aspergillus niger works efficiently and better at a temperature of $25^{\circ} \mathrm{C}$ rather than at a temperature of $37^{\circ} \mathrm{C}$. This is in accordance with [15] that microorganism works best at different optimum temperature.

It was observed that during the third week of hydrolysis, the concentration of reducing sugar produced by the three papers reduced drastically. One of the major reasons behind this is the decrease in the number of microorganisms present during the hydrolysis. This happens when the microorganism which initially multiplies during the log phase of microbial growth begins to die. A reduction in the number of microorganism occurs during the death stage of microbial growth and this is due to the fact that the microorganisms begin to eat up themselves when there is lack of nutrient which keeps them alive [13]. Evident is the difference in the sugar production from three (3) various waste papers when levels of maximum bioconversion were reached. The comparative analysis is shown in Figures 9a-f.

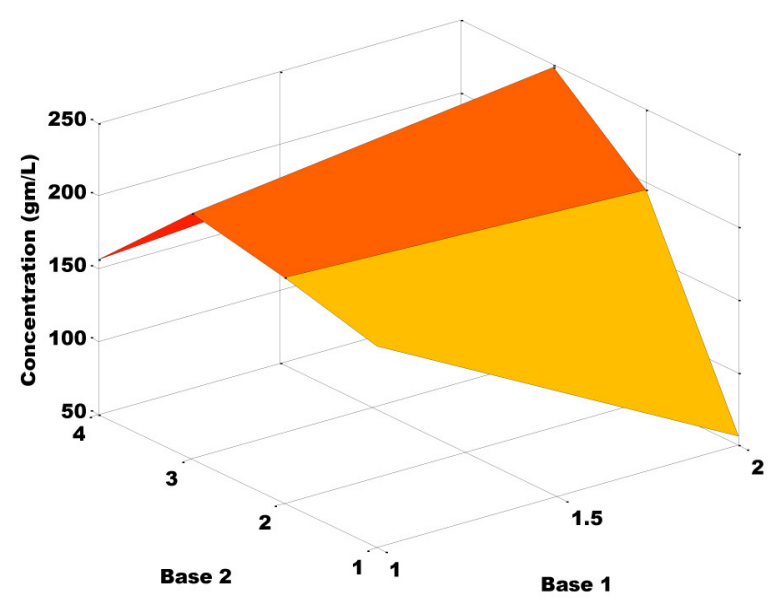

Figure 9a. 3D of varying concentration newspaper product over a formative base
The comparative analysis of Pseudomonas aeruginosa and Aspergillus niger on newspaper at $37^{\circ} \mathrm{C}$ is shown in Figure 9a. The concentration of sugar production in newspaper may be low compared with other biomass. However, the bellcurve features of the 3D plot may result from the properties of the newspaper. More scientific was the contour base map generated by the 3D plot (Figure 9b). The two colour arrow-shape tends to magnitude 3 showing that the production of sugar using newspaper could be optimized with more reactive enzymes.

The comparative analysis of Pseudomonas aeruginosa and Aspergillus niger on office paper at $37^{\circ} \mathrm{C}$ is shown in Figure 9c. The concentration of sugar production in office paper was the highest compared with other biomasses. The features of the $3 \mathrm{D}$ plot may be a result of the properties of the office paper i.e. not much ink on the paper. More scientific was the contour base map generated by the 3D plot (Figure 9d). The five colour arrow-shape tends to magnitude 2 showing that the production of sugar using office paper could be more dynamic than just using enzymes.

The comparative analysis of Pseudomonas aeruginosa and Aspergillus niger on the foolscap paper at $37^{\circ} \mathrm{C}$ is shown in Figure 9e. The concentration of sugar production in the office paper was high. The negative parabolic features of the 3D plot may be as a result of the properties of the foolscap paper i.e. as discussed earlier. More scientific was the contour base map generated by the 3D plot (Figure 9f). The contour map was more distributive in Pseudomonas aeruginosa than Aspergillus niger. Hence, the foolscap may yield better when other labo-

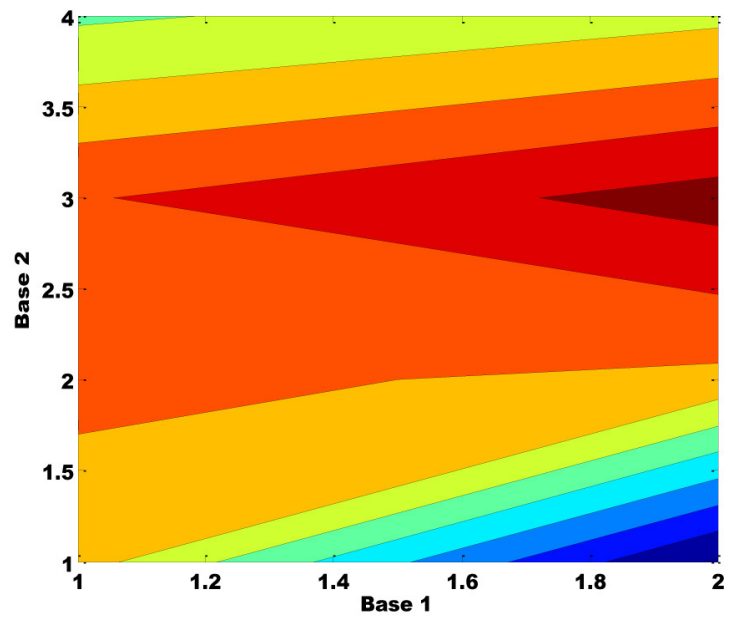

Figure 9b. Contour of base mapping for newspaper product 


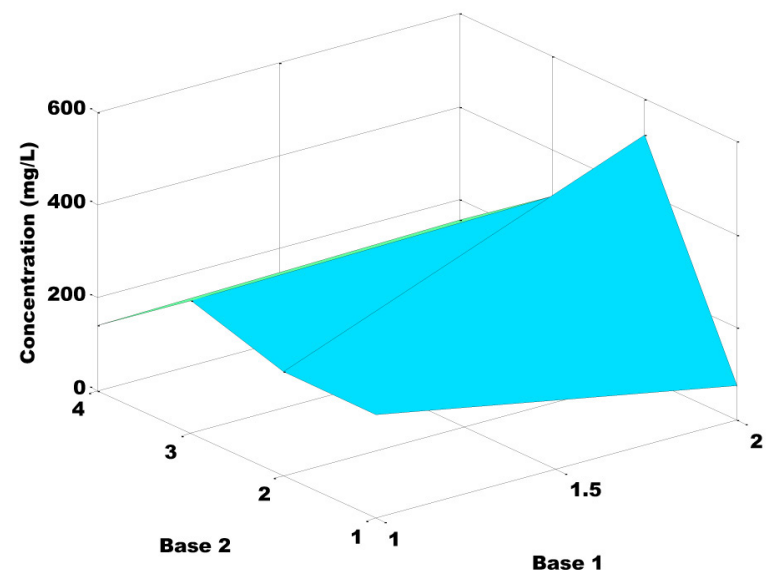

Figure 9c. 3D of varying concentration office paper over a formative base

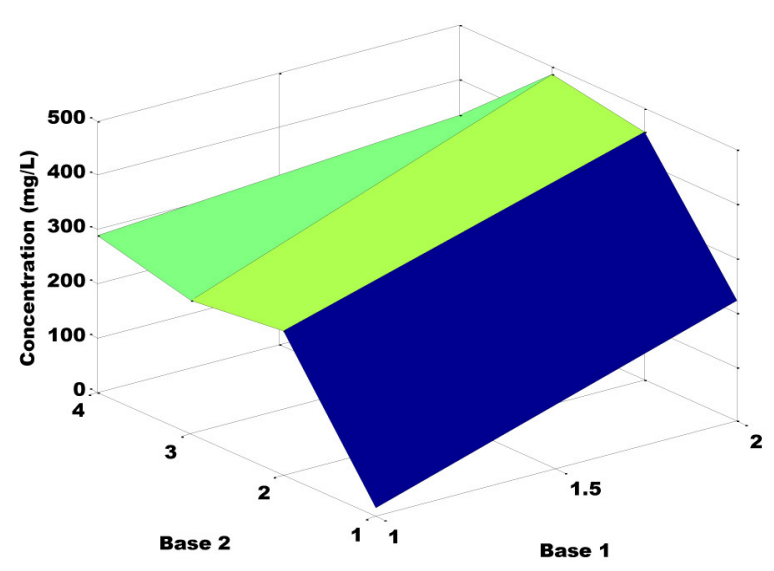

Figure 9e. 3D of varying concentration foolscap paper over a formative base

ratory parameters (e.g. temperature, time etc.) are optimized than using the enzymes.

The currently used paper, which is part of organic solid waste, is treated as typical waste of no value and as a result, it is exposed to solid waste management procedures [8]. The chemical nature of waste paper suggests that these waste materials could be developed as a resource of bioenergy by converting their cellulose components into fermentable sugars [7]. The bioconversion of waste cellulose does not only limit the huge amounts of solid waste but also addresses the issue of clean and green energy.

\section{CONCLUSIONS}

The investigation showed that Pseudomonas aeruginosa and Aspergillus niger are good

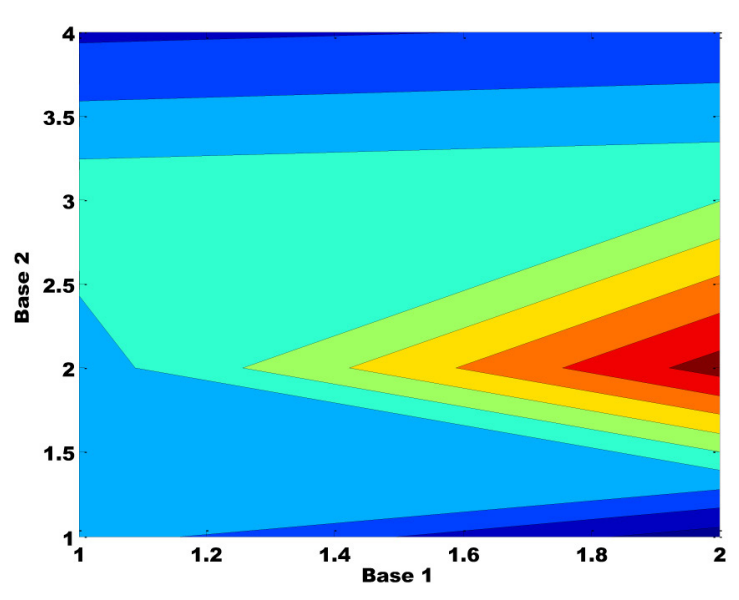

Figure 9d. Contour of base mapping for office paper

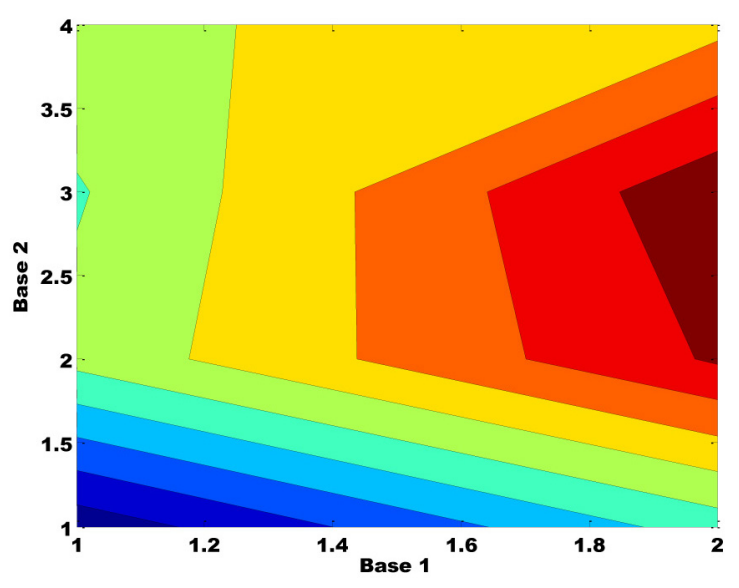

Figure 9f. Contour of base mapping for foolscap paper

enzyme catalysts for enzymatic hydrolysis of waste paper as substrate to fermented sugar. The most promising substrate of the tested waste papers were the office paper and foolscap paper, which produced reducing sugar at a maximum concentration of 523.333 and $486.66 \mathrm{mg} / \mathrm{L}$, respectively, after one and two weeks using Pseudomonas aeruginosa at $37^{\circ} \mathrm{C}$. The most promising substrate hydrolysed using Aspergillus niger, was the office paper, which produced reducing sugar at a maximum concentration of $365 \mathrm{mg} / \mathrm{L}$ at an optimum temperature of $25^{\circ} \mathrm{C}$. This research work proves the environmental advantage of limiting the accumulation of solid waste materials on valuable land.

\section{Acknowledgements}

The authors appreciate the partial sponsorship of Covenant University. 


\section{REFERENCES}

1. Chandel A., Chan E.S, Rudravaram R, Narasu M.L., Ravindra L.R., Venkateswar R., Pogaku R., 2007. Economics and environmental impact of bioethanol production technologies: an appraisal. Biotechnology and Molecular Biology Review, 2, 14-32.

2. Dutta R. Fundamentals of biochemical engineering. India: Springer, 2008.

3. Göttsching L., Pakarinen H., Yhdistysc S.P., 2000. Recycled Fiber and Deinking. Technical Association of the Pulp and Paper Industry Finland: Fapet Oy. Science:649.

4. Guerfali M., Saidi A., Gargouri A., Belghith H., 2015. Enhanced enzymatic hydrolysis of waste paper for ethanol production using separate saccharification and fermentation. Tunisha: PubMed.

5. Henning J., Jan B.K., Claus F., 2007. Enzymatic conversion of lignocellulose into fermentable sugars: challenges and opportunities. Biofuels, Bioproducts, Biorefinig, 1(2), 119-134.

6. Hui C., Richard A., Venditti H., Jameel O., Sunkyu P., 2012. Enzymatic Hydrolysis of Recovered Office Printing Paper with Low Enzyme Dosages to Produce Fermentable Sugars. Appl. Biochem. Biotechnology, 166, 1121-1136,

7. Jiang L., Zhang A., Zhao Z., He F., Li H., Wu N., 2016. The comparison of obtaining fermentable sugars from cellulose enzymatic hydrolysis and fast pyrolysis. Bioresources Technology, 200, 8-13.

8. Karima A., Mayo A.W., 2016. Challenges and prospects of private sector participaton in solid waste management in Dar es Salaam, Tanzania. Habitat Interenational, 53, 195-205.

9. Kassim E.A., El-Shahed A.S., 1986. Enzymatic and chemical hydrolysis of certain cellulosic materials. Agricultural Wastes, 17(3), 229-233.

10. Kerr R., 2007. Global Warming is Changing the world. Science, 188-190.

11. Khim H., Chu X.F., 2013.x Enzymatic conversion of newspaper and office paper to fermentable sug- ars - Process Safety and Environmental Protection, 91, 23-130.

12. Meizah K., Obiri-Danso K., Kadar Z., Fi-Baffoe B., Mensah M.Y., 2015. Municipal solid waste characterization and quantification as a measure towards effective waste management in Ghana. Waste Management, 15-27

13. Modupe E.O., Prof. Abiodun J.O., Prof. Adesola A.A., 2016. The Effect of Different Starter Cultures on the Protein Content in Fermented African Locust Bean (Parkia Biglobosa) Seeds. International Journal of Engineering Research \& Technology, 5(4), 249-255.

14. Mokatse K.M.P., Mhlanga H.S., Wyk van J.P.H., 2016. Relative saccharification and initial degradation rates of different waste paper materials by cellulase from Trichoderma viride. Journal of Applied. Bioscience, 105, 10183-10190.

15. Ojewumi M.E., Omoleye J.A., Ajayi A.A., 2016. Optimum fermentation temperature for the protein yield of parkia biglobosa seeds (Iyere), in: Procedding of the $3^{\text {rd }}$ International confernece on African Development Issues (CUICAD), pp. 548-587. Ota, Ogun State, Nigeria.

16. Salam M.A., Paritush C.P., Ariful I., Maksudur R.K., Mohammad R.U., Islam M.A., 2013. Conversion of Cellulosic waste into fermentable sugar: Process optimization. Journal of Chemical Engineering IEB, 28(1), 27-31.

17. Wani K.A., Rao R., 2013. Bioconversion of garden waste, kitchen waste and cow dung into value - added products using earthworm Eisenia fetida. Saudi Journal of Biological Sciences, 149-154.

18. Wayman M., Chen S., Doan K., 1992. Bioconversion of waste paper to ethanol. Process Biochemical, 27(4), $239-245$.

19. Khim Hoong ChuSearch for articles by this authorWyk J.V., Mogale M., Moroka K., 1999. Bioconversion of waste paper materials to sugars: an application illustrating the environmental benefit of enzymes. Biochemical Education, 7, 227-228. 